\title{
PENGARUH KESADARAN MEREK DAN KEPERCAYAAN KONSUMEN ATAS MEREK TERHADAP KEPUTUSAN PEMBELIAN ULANG PRODUK SMARTPHONE SAMSUNG
}

\author{
(STUDI KASUS PADA MAHASISWA UNIVERSITAS \\ DR. SOETOMO SURABAYA)
}

Agustiawan Djoko Baruno

Fakultas Ekonomi dan Bisnis Universitas Dr Soetomo Surabaya

E-mail : \{ HYPERLINK "mailto:agustiawanb@unitomo.ac.id" \}

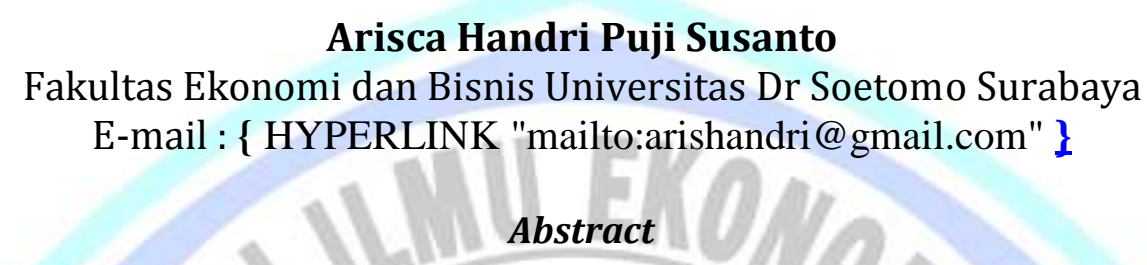

This study aims to determine: (1) the influence of brand awareness on the decision to repurchase Samsung smartphone products (2) the influence o brand trust on the decision to repurchase Samsung smartphone products (3) the influence of brand awareness and brand trust on the decision to repurchase Samsung smartphone products (4) dominant factors that influence the decision to repurchase Samsung smartphone product. The data used in the this research are primary. Primary data in this research were obtained from a questionnairen that the measurement using a likert scale and statistically processed using multiple linier regression formula by using SPSS version 23. Based on the result of this research is that Test F variabel X1 (Brand Awareness) and X2 (Brand Trust) simultaneously influence the repurchase (Y). This is evidenced as $53,221 \mathrm{~F}$ count $>F$ table 3,13 . While the $t$ test, there is no partial influence Brand awareness (X1) on the repurchase decision (Y), it is proved because -1,599 $t$ count $\geq-1,99444 t$ table and Brand trust (X2) have partial influence on the repurchased decision (Y), it is proved because 9,779 $t$ count $>1,99444 t$ table. Brand trust is the most dominant variabel on repurchased decision $(Y)$ it is proved because 9,779 $t$ count $>1,99444 t$ table. The magnitude of the influence of the independent variables were analyzed together the dependent variable $58,9 \%$, while the remaining $41,1 \%$ is influenced by other variables that are not in this research.

Keyword: Brand Awareness, Brand Trust.

\section{Abstrak}

Penelitian ini bertujuan untuk mengetahui: (1) pengaruh kesadaran merek terhadap keputusan pembelian kembali produk smartphone Samsung (2) pengaruh kepercayaan merek terhadap keputusan pembelian kembali produk smartphone Samsung (3) pengaruh kesadaran merek dan kepercayaan merek terhadap keputusan untuk membeli kembali produk smartphone Samsung (4) faktor dominan yang mempengaruhi keputusan untuk membeli kembali produk smartphone Samsung. Data yang digunakan dalam penelitian ini adalah primer. Data primer dalam penelitian ini diperoleh dari kuesioner yang pengukurannya menggunakan skala likert dan diolah secara statistik menggunakan rumus regresi linier berganda dengan menggunakan SPSS versi 23. Berdasarkan hasil penelitian ini adalah bahwa Uji F variabel X1 (Kesadaran Merek) dan X2 (Kepercayaan Merek) secara bersamaan 
mempengaruhi pembelian kembali (Y). Ini dibuktikan dengan 53,221 F hitung> F tabel 3,13. Sedangkan uji t, tidak ada pengaruh parsial Brand awareness (X1) pada keputusan repurchase (Y), terbukti karena $-1,599$ t hitung $\geq-1,99444 \mathrm{t}$ tabel dan kepercayaan Brand (X2) memiliki pengaruh parsial terhadap pembelian kembali keputusan (Y), terbukti karena 9,779 t hitung> 1,99444 t tabel. Kepercayaan merek merupakan variabel yang paling dominan pada keputusan pembelian kembali (Y) terbukti karena 9,779 t hitung> 1,99444 t tabel. Besarnya pengaruh variabel independen dianalisis bersama-sama dengan variabel dependen sebesar 58,9\%, sedangkan sisanya $41,1 \%$ dipengaruhi oleh variabel lain yang tidak dalam penelitian ini.

Keyword: Brand Awareness, Brand Trust,

\section{PENDAHULUAN}

Industri telepon seluler dewasa ini adalah salah satu industri yang semakin ketat persaingannya, berkembang pesat sejalan dengan perkembangan zaman dan teknologi. Perkembangan ini tidak lain di sebabkan oleh kebutuhan manusia yang semakin kompleks cenderung menginginkan hal yang instan, praktis dan efisien.

Ada beberapa produk telepon seluler yang mereknya telah begitu melekat di masyarakat Indonesia. Salah satunya, Samsung. Samsung merupakan salah satu merek yang menghipnotis banyak masyarakat dengan keunggulan dan kelebihannya terutama dengan jajaran produk smartphone samsung galaxynya. Terbukti dalam 2 tahun terakhir telah merajai pasar gadget di Indonesia. Kondisi ini menunjukkan bahwa kebutuhan, pengetahuan dan kepekaan konsumen terhadap gadget yang canggih semakin meningkat.

\begin{tabular}{|c|c|c|c|c|c|c|}
\multicolumn{7}{c|}{ Tabel 1. Data Smartphone Q4'2014 - Q4'2016 } \\
\hline \multirow{2}{*}{ Vendor } & Q4'2014 & Q4'2014 & Q4'2015 & Q4'2015 & Q4'2016 & Q4'2016 \\
& $\begin{array}{c}\text { Shipment } \\
\text { Volumes }\end{array}$ & $\begin{array}{c}\text { Market } \\
\text { Share }\end{array}$ & $\begin{array}{c}\text { Shipment } \\
\text { Volumes }\end{array}$ & $\begin{array}{c}\text { Market } \\
\text { Share }\end{array}$ & $\begin{array}{c}\text { Shipment } \\
\text { Volumes }\end{array}$ & $\begin{array}{c}\text { Market } \\
\text { Share }\end{array}$ \\
\hline \multirow{2}{*}{ Samsung } & 75,1 & $19,9 \%$ & 85,6 & $21,4 \%$ & 77,5 & $17,7 \%$ \\
\hline Apple & 74,5 & $19,7 \%$ & 74,8 & $18,7 \%$ & 78,3 & $17,8 \%$ \\
\hline \multirow{2}{*}{ Huawei } & 32,6 & $6,3 \%$ & 32,4 & $8,1 \%$ & 44,9 & $10,2 \%$ \\
\hline Others & 174,0 & $46,1 \%$ & 168,3 & $42,1 \%$ & 182,9 & $41,7 \%$ \\
\hline
\end{tabular}

\section{Sumber : IDC.com}

Dilihat dari tabel tersebut terlihat jelas penjualan beberapa perusahaan smartphone mengalami peningkatan. pada kuartal 4 tahun 2014 sampai 2015 menunjukkan data penjualan smartphone, Samsung mengalami kenaikan penjualan sebesar 10,5 juta, Apple mengalami kenaikan sebesar 0,3 juta dan huawei sendiri mengalami penurunan sebesar 0,2 juta, pada kuartal 4 tahun 2015 sampai 2016, 
Samsung mengalami penurunan sebesar 8,1 juta, Apple mengalami kenaikan sebesar 3,5 juta dan huawei mengalami kenaikan sebesar 12,5 juta

Pada kuartal 4 tahun 2014-2015 market share beberapa vendor mengalami penurunan dan kenaikan, Samsung mengalami kenaikan sebesar 1,5\%, Apple mengalami penurunan sebesar $1 \%$ dan huawei mengalami kenaikan sebesar 1,8 \%. Pada kuartal 4 tahun 2015 sampai 2016, Samsung mengalami penurunan sebesar $3,7 \%$, Apple mengalami penurunan sebesar 0,9\% dan huawei mengalami kenaikkan sebesar 2,1\%. Dilihat dari data penjualan dan pangsa pasar terjadi persaingan ketat antara vendor Samsung dan Apple. Samsung pada kuartal 42014 sampai 2015 menjadi jawara dengan jumlah penjualan unit dan pangsa pasar terbesar diantara vendor smartphone lainnya, tetapi pada kuartal 4 tahun 2016 samsung harus merelakan posisinya kepada Apple. Tidak lain penurunan ini disebabkan oleh kecacatan produk Samsung terutama Samsung galaxy note 7, masalah galaxy note 7 ini terletak pada baterai sehingga samsung galaxy note 7 ini suatu saat dapat meledak ketika berada pada suhu panas tertentu. Dengan adanya masalah pada jajaran produk smartphone samsung terutama seri note pihak yang dirugikan adalah konsumen dan produsen itu sendiri. Konsumen khawatir dengan keamanan penggunaan smartphone mereka, sedangkan dari pihak produsen, hal ini mempengaruhi kepercayaan konsumen terhadap merk Samsung sendiri. Samsung harus melakukan langkah yang tepat terhadap masalah ini, sebab jika kepercayaan konsumen menurun maka jumlah penjualan smartphone juga ikut turun, karena konsumen khawatir dengan keamanan produk smartphone yang mereka pakai dan enggan untuk membeli kembali produk smartphone samsung

Selain itu, dengan adanya insiden ini bisa merusak citra, reputasi merek smartphone samsung itu sendiri, konsumen yang tidak yakin dengan merek Samsung akan beralih ke merek yang lain. Reputasi Samsung sebagai vendor smartphone yang memiliki kualitas yang terbaik berangsur-angsur akan turun dan merek samsung tidak akan di perhatikan lagi. Merek Samsung perlahan-lahan bisa pudar dari ingatan konsumen, dari tingkatan top of mind ke brand recall, atau lebih parah jika dampai ke tingkatan brand recognition dan akhirnya setara dengan merek yang lain. Hal itu merupakan masalah dalam pembelian ulang produk smartphone samsung, dimana akan berakibat penjualan produk smartphone menurun dari satu periode ke periode berikutnya.

Berdasarkan uraian latar belakang tersebut diatas, maka pokok-pokok masalah dalam penelitian ini dapat dirumuskan sebagai berikut:

1. Apakah terdapat pengaruh secara parsial kesadaran merek dan kepercayaan merek terhadap keputusan pembelian ulang produk smartphone samsung ?

2. Apakah terdapat pengaruh secara simultan kesadaran merek dan kepercayaan merek terhadap keputusan pembelian ulang produk smartphone samsung ?

3. Diantara faktor kesadaran merek dan kepercayaan merek manakah yang berpengaruh dominan terhadap keputusan pembelian ulang produk smartphone samsung?

\section{KERANGKA TEORITIS}

\section{Perilaku Konsumen}

Sumarwan (2015:5) menyatakan perilaku konsumen adalah kegiatan, tindakan, serta proses psikologis yang mendorong tindakan tersebut pada saat sebelum membeli, ketika membeli, menggunakan, menghabiskan produk dan jasa setelah melakukan hal-hal di atas atau kegiatan mengevaluasi.

\section{Faktor-faktor Utama Penentu Keputusan Pembelian Konsumen}


Menurut Sangadji dan Sopiah (2013:24) ada tiga faktor utama yang mempengaruhi konsumen untuk mengambil keputusan, yaitu:

1) Faktor Psikologis

Faktor psikologis mencakup persepsi, motivasi, pembelajaran, sikap dan kepribadian. Sikap dan kepercayaan merupakan faktor psikologis yang memengaruhi keputusan pembelian konsumen. Sikap adalah suatu kecenderungan yang dipelajari untuk bereaksi terhadap penawaran produk dalam situasi dan kondisi tertentu secara konsisten.

2) Faktor Situasional

Faktor situasional mencakup keadaan sarana dan prasarana tempat belanja, waktu berbelanja, penggunaan produk dan kondisi saat pembelian. Keadaan sarana dan prasarana tempat belanja mencakup tempat parkir, gedung, eksterior dan interior toko, pendingin udara, penerangan/pencahayaan, tempat ibadah, dan sebagainya.

3) Faktor Sosial

Faktor sosial mencakup undang-undang/peraturan, keluarga, kelompok, referensi, kelas sosial, dan budaya.

\section{Pengertian Merek}

Direktorat Jenderal Hak Kekayaan Intelektual (Dirjen HAKI) dalam Swasty (2016:4) menerangkan merek yakni suatu tanda yang berupa gambar, nama, kata, huruf-huruf, angka-angka, susunan warna atau kombinasi dari unsur-unsur tersebut yang memiliki daya pembeda dan digunakan dalam kegiatan perdagangan barang dan jasa.

\section{Manfaat Merek}

Tjiptono (2011:43) memaparkan manfaat merek bagi produsen dan konsumen sebagai berikut:

1. Bagi produsen

a) Sarana identifikasi untuk memudahkan proses penanganan atau pelacakan produk bagi perusahaan, terutama dalam pengorganisasian sediaan dan pencatatan akuntansi

b) Bentuk proteksi hukum terhadap fitur atau aspek produk yang unik

c) Signal tingkat kualitas bagi para pelanggan yang puas, sehingga mereka bisa dengan mudah memilih dan membelinya lagi di lain waktu

2. Bagi Konsumen

a) Identifikasi

Bisa dilihat dengan jelas; memberikan makna bagi produk; gampang mengidentifikasi produk yang dibutuhkan atau dicari

b) Praktikalitas

Memfasilitasi penghematan waktu dan energi melalui pembelian ulang identik dan loyalitas

c) Jaminan

Memberikan kepastian bahwa mereka bisa mendapatkan kualitas yang sama sekalipun pembelian dilakukan pada waktu dan di tempat berbeda

\section{Pengertian Ekuitas Merek}

Menurut Swasty (2016:108) mendefinisikan ekuitas merek adalah keinginan suatu pemegang merek untuk melanjutkan menggunakan suatu merek atau tidak. Pengukuran dari ekuitas merek sangatlah berhubungan kuat dengan kesetiaan dan 
bagian pengukuran dari pengguna baru yang menjadi pengguna yang setia. Ekuitas merek atau kekuatan merek adalah kontrol dari pembelian dengan menggunakan merek, dan merek sebagai aset yang dapat dimanfaatkan untuk mengahsilkan pendapatan.

\section{Pengertian Kesadaran Merek}

Brand Awareness Darmadi (2004: 6) merupakan salah satu elemen inti dalam brand equity. Kesadaran (awareness) menggambarkan keberadaan merek di dalam pikiran konsumen, yang dapat menjadi penentu dalam beberapa kategori dan biasanya mempunyai peranan kunci dalam brand equity.

\section{Indikator Kesadaran Merek}

Menurut Rangkuti dalam Muzaqqi (2016:28) ada empat tingkat kesadaran merek dari tingkat yang paling tinggi sampai yang paling rendah yaitu :

1. Unware of brand (tidak menyadari merek)

2. Brand recognition (pengenalan merek)

3. Brand recall (pengingatan kembali terhadap merek)

4. Top of mind (puncak pikiran)

\section{Mencapai Kesadaran Merek}

Pengenalan merek merupakan ukuran brand awareness responden. Pengenalan merek sangat penting untuk mengetahui sampai tingkat mana para pembeli mengetahui ciri-ciri suatu merek. Dalam hal ini pengenalan merek merupakan pengenalan atribut merek secara fisik, seperti warna, ukuran dan bentuk sehingga kemasan dan desain produk sangat penting. Kesan merek keseluruhan terbentuk dari tiga elemen, yaitu;

1. Pengenalan merek (Brand Recognition)

2. Sikap konsumen (Attitude)

3. Kepercayaan konsumen terhadap produk

\section{Pengertian Kepercayaan Merek}

Menurut Delgado dalam Wulansari (2013:391) Kepercayaan merek adalah perasaan aman yang dimiliki konsumen akibat dari interaksinya dengan sebuah merek, yang berdasarkan presepsi bahwa merek tersebut dapat diandalkan dan bertanggung jawab atas kepentingan dan keselamatan dari konsumen.

\section{Indikator Kepercayaan Merek}

Menurut Delgado dalam Wulansari (2013:391) ada dua indikator variabel yang mempengaruhi merek (Brand Trust)

1. Brand Realibility

Brand Realibility adalah kehandalan merek yang bersumber pada keyakinan konsumen bahwa produk tersebut mampu memenuhi nilai yang dijanjikan atau dengan kata lain persepsi bahwa merek tersebut mampu memenuhi kebutuhan dan memberikan kepuasan.

2. Brand Intentions

Brand Intentions atau minat pada merek mencerminkan keyakinan konsumen bahwa merek tersebut mampu mengutamakan kepentingan konsumen ketika masalah dalam konsumsi produk muncul secara tidak terduga.

\section{Pengertian Keputusan Pembelian Ulang}

Pembelian ulang menurut Peter dan Olsen (2002) adalah kegiatan pembelian yang dilakukan lebih dari satu kali atau beberapa kali. Kepuasan yang diperoleh 
seorang konsumen dapat mendorong ia melakukan pembelian ulang menjadi loyal terhadap produk tersebut sehingga konsumen dapat menceritakan hal-hal yang baik kepada orang lain.

\section{Indikator Keputusan Pembelian Ulang}

Bolton dalam Wulansari (2013:390) yang disesuaikan dengan objek penelitian pengguna Smartphone Samsung, sehingga indikator variabel keputusan pembelian yang digunakan dalam penelitian ini yaitu :

1. Pembelian kembali produk yang sama di masa yang akan datang.

2. Keputusan jumlah pembelian yang dilakukan konsumen

\section{KERANGKA KONSEPTUAL}

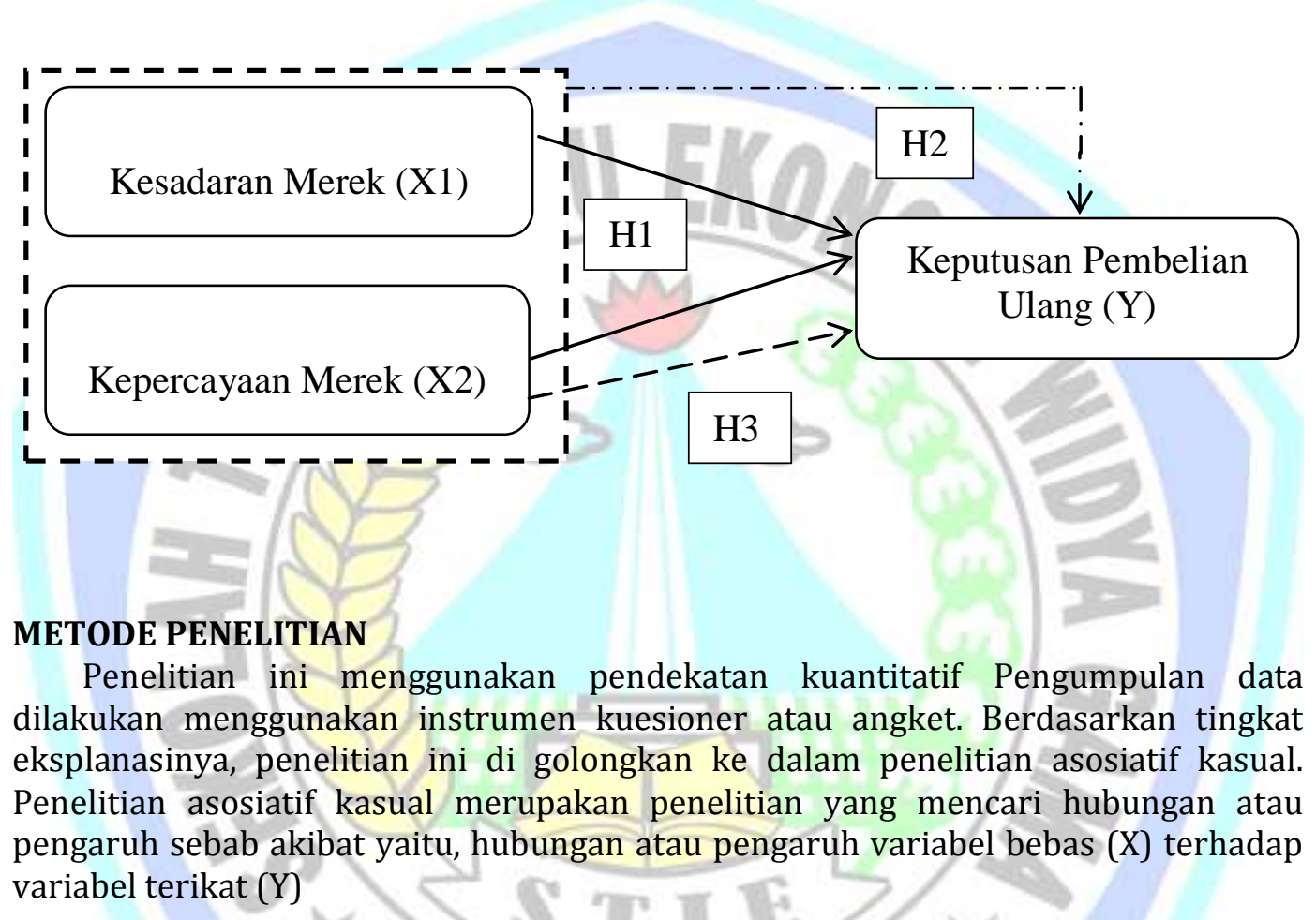

\section{POPULASI DAN SAMPEL}

Populasi dalam penelitian ini adalah mahasiswa Universitas Dr. Soetomo Surabaya jenjang Strata satu (S1) Bersumber dari rekapitulasi mahasiswa Her tahun akademik 2016/2017 diperoleh data mahasiswa Universitas Dr Soetomo tahun 2013 sampai dengan tahun 2016 sebagai berikut: 463 fakultas FIA, 335 fakultas pertanian, 318 fakultas FKIP, 1299 fakultas Ekonomi dan Bisnis, 803 Fakultas Teknik, 425 fakultas Hukum, 282 fakultas Sastra, 535 fakultas Fikom sehingga total keseluruhan 4460 mahasiswa. (2013:4)

Sampel diperoleh dengan, Green dalam Yunita Nirmala dan Hartono Subagyo

$$
\begin{gathered}
\text { Jumlah sampel }=50+8(\mathrm{n}) \\
=50+8(3) \\
=74
\end{gathered}
$$

Jadi, sampel yang digunakan dalam penelitian ini adalah 74 orang.dengan pertimbangan jumlah tersebut sudah mencerminkan ukuran sampel yang layak di perkuat dengan pendapat Roescoe point 1 dan 3 ; 
1. Ukuran sampel yang layak dalam penelitian adalah antara 30 dan sampai dengan 500.

2. Dalam penelitian multivariate, ukuran sampel sebaiknya minimal 10 kali dari jumlah variable yang diteliti, jumlah sampel 10 × $3=30$ sampel.

\section{VARIABEL OPERASIONAL}

Variabel-variabel yang digunakan dalam penelitian ini : Variabel Terikat (Y) adalah keputusan pembelian ulang dan variabel bebas (X) yang terdiri dari ; Kesadaran Merek (X1) dan Kepercayaan Merek (X2)

\section{INDIKATOR VARIABEL}

\section{A. Variabel Bebas (X)}

1. Kesadaran merek berkaitan dengan kekuatan merek memberi jejak di memori, yang dapat diukur sebagai kemampuan pelanggan untuk mengidentifikasi merek di bawah kondisi yang berbeda.
a. Puncak pikiran (Top of Mind) (X1.1)
b. Pengingat Merek (Brand Recall) (X1.2)
c. Pengenalan Merek (Brand Recognition) (X1.3)
d. Tidak Mengenal Merek (Brand Unware) (X1.4)

2. Menurut Delgado dalamwulansari (2013:391), Kepercayaan merek adalah perasaan aman yang dimiliki konsumen akibat dari interaksinya dengan sebuah merek, yang berdasarkan resepsi bahwa merek tersebut dapat di andalkan dan bertanggung jawab atas kepentingan dan keselamatan dari konsumen. Indikator variabel dari kepercayaan merek adalah :

a. Brand Realibility (X2.1)

b. Brand Intention (X2.2)

\section{B. Variabel Terikat (Y)}

Menurut Bolton dalamWulansari (2013:390) yang disesuaikan dengan objek penelitian pengguna Smartphone Samsung, sehingga indikator variabel keputusan pembelian dalam penelitian ini yaitu :

a. Pembelian kembali produk yang sama di masa yang akan datang.

b. Keputusan jumlah pembelian yang dilakukan konsumen.

\section{JENIS DATA DAN SUMBER DATA}

\section{Jenis Data}

Penelitian ini menggunakan jenis data kuantitatif yang berupa opini dan pengalaman yang diperoleh dari responden, dimana responden memberikan respon secara tertulis sebagai tanggapan atas pernyataan yang diberikan dalam kuesioner.

\section{Sumber Data}

Dalam penelitian ini sumber data yang digunakan adalah sebagai berikut:

a. Data primer dalam penelitian ini adalah data yang diperoleh langsung dari responden melalui penyebaran kuesioner pada mahasiswa Universitas Dr. Soetomo Surabaya.

b. Data sekunder dalam penelitian ini adalah data rekapitulasi mahasiswa yang didapat dari Universitas Dr. Soetomo Surabaya berkenaan sebagai objek penelitian ini

\section{TEKNIK PENGUMPULAN DATA}


Penelitian ini dikumpulkan dengan menggunakan metode kuesioner yaitu dengan cara menyebarkan daftar pernyataan kepada seluruh responden yang dipilih.

\begin{tabular}{|l|l|c|c|}
\cline { 2 - 4 } TEKNIK & \multicolumn{1}{|c|}{ Variabel } & Cronbach's Alpha & Keterangan \\
\cline { 2 - 4 } & Kesadaran Merek & 0,612 & Reliabel \\
\cline { 2 - 4 } & Kepercayaan Merek & 0,873 & Reliabel \\
\cline { 2 - 4 } & Keputusan Pembelian Ulang & 0,688 & Reliabel \\
\cline { 2 - 4 }
\end{tabular}

ANALISIS

Uji Validitas

Menurut Duwi Priyatno (2016:154) pengambilan keputusan berdasarkan nilaimaka dengan membandingkan nilai $r$ hitung dengan ketentuan sebagai berikut : Jika nilai $r$ hitung $<\mathrm{r}$ tabel maka item dinyatakan tidak valid Jika nilai $r$ hitung $>t$ tabel maka item dinyatakan valid

Tabel 2. Hasil Uji Validitas

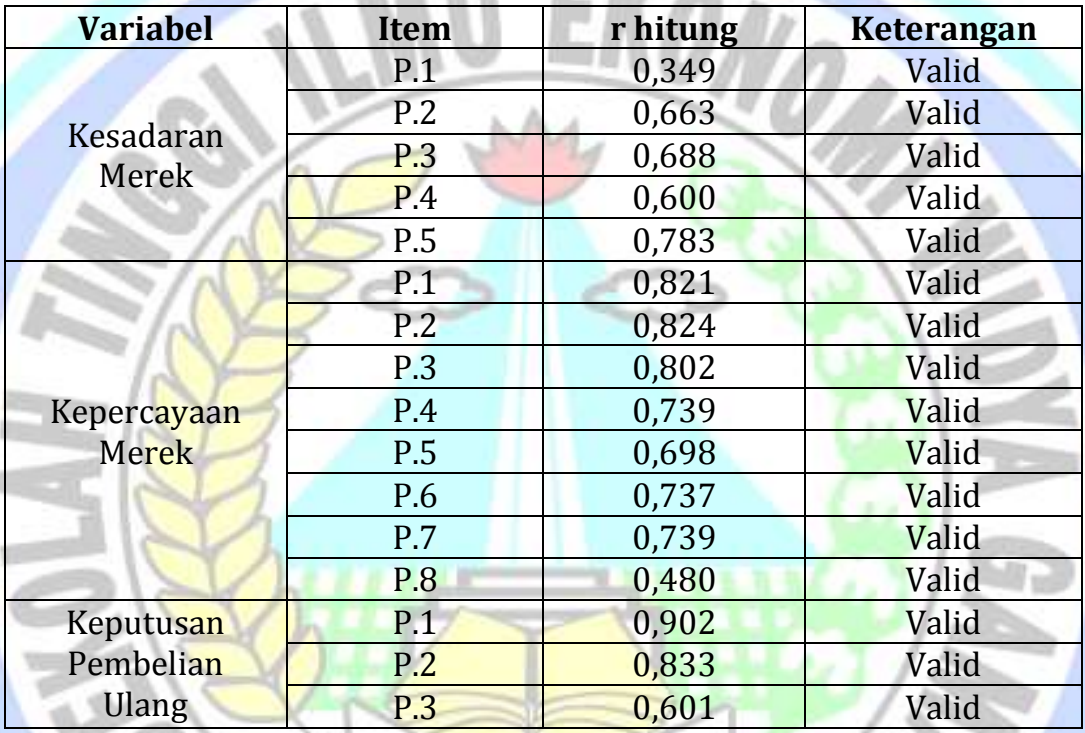

\section{Sumber: Hasil Pengolahan Data Primer Tahun 2017}

Uji Reabilitas

\section{Tabel 3. Hasil Uji Reabilitas}

\section{Sumber : Hasil Olahan Data Tahun 2017}

Uji reliabilitas dilakukan untuk menunjukkan konsistensi dari alat ukur dalam mengukur gejala yang sama di lain kesempatan. Pengujian reliabilitas dalam penelitian ini menggunakan Uji Statistik Cronbach's Alpha (Koeisien Alfa) dimana suatu kuesioner dikatakan reliabel apabila memiliki nilai Cronbach Alpha >0,60, maka item pernyataan tersebut reliabel.

\section{UJI ASUMSI KLASIK}

Uji Normalitas 
Pengujian normalitas menggunakan teknik analisis Kolmogorov-Smirnov dan untuk perhitungannya menggunakan progam SPSS 23 for Windows. Data dikatakan berdistribusi normal apabila nilai signifikansi lebih besar dari 0,05 pada taraf signifikansi a=0,05. Hasil uji variabel penelitian sebagai berikut :

\section{Tabel 4. Hasil Uji Normalitas}

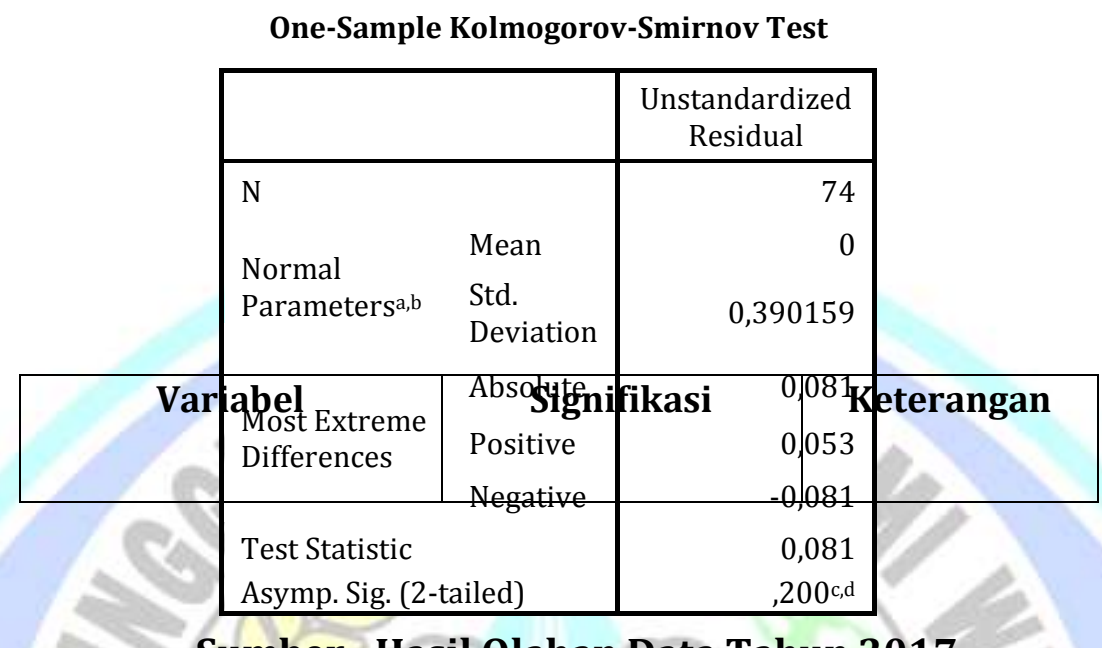

\section{Uji Multikolonieritas}

Gejala multikolinearitas terjadi bila terdapat korelasi diantara variabel-variabel independen. Identifikasi secara statistik mengenai ada atau tidaknya gejala multikolinearitas dalam regresi dapat dilihat dari variance inflation factor (VIF). Jika VIF yang dihasilkan diantara 1-10 maka tidak terjadi multikolonieritas

\section{Tabel 5. Hasil Uji Multikolonieritas}

Coefficients ${ }^{\mathrm{a}}$

\begin{tabular}{|ll|r|r|}
\hline \multirow{2}{*}{ Model } & & \multicolumn{2}{|c|}{ Collinearity Statistics } \\
\cline { 3 - 4 } & & Tolerance & \multicolumn{1}{c|}{ VIF } \\
\hline 1 & X1 &, 787 & 1,271 \\
& X2 &, 787 & 1,271 \\
\hline
\end{tabular}

a. Dependent Variable: X3

Sumber: Hasil Olahan Data Primer Tahun 2017

\section{Ujii Linieritas}

Uji linieritas adalah bertujuan untuk mengetahui hubungan antara variabel bebas dan variabel terikat linier atau tidak. Kriteria pengujian linieritas adalah jika nilai signifikasi lebih besar dari 0,05, maka hubungan antara variabel bebas dan variabel terikat adalah linier.

Tabel 6. Hasil Uji Linieritas 


\begin{tabular}{|l|c|c|}
\hline Kesadaran Merek & 0,329 & Linier \\
\hline Kepercayaan Merek & 0,657 & Linier \\
\hline
\end{tabular}

\section{Sumber: Hasil Olahan Data Primer Tahun 2017}

Uji

Coefficients $^{\mathbf{a}}$

\section{Heterokedastisitas}

Heterokedastisitas terjadi apabila terdapat hubungan antara nilai residual dengan variabel bebas dalam model regresi linier. Hasil uji heterokedastisitas dengan menggunakan uji Glejser. nilai signifikansi lebih besar dari 0,05 sehingga dapat disimpulkan bahwa model regresi pada penelitian ini tidak terjadi heterokedastisitas.

\section{Tabel 7. Hasil Uji Heterokedastisitas}

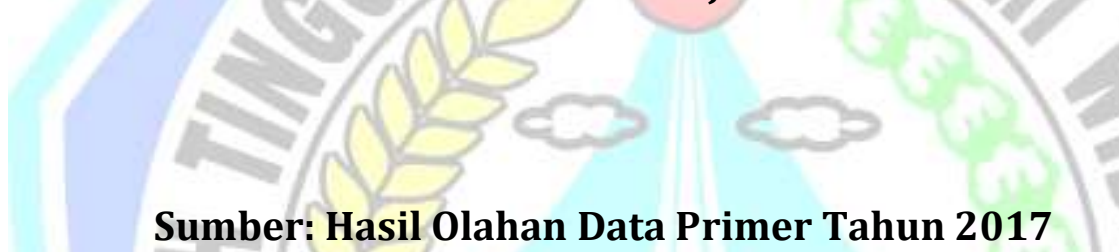

\section{PENGUJIAN TERHADAP HIPOTESIS}

Penelitian ini bertujuan untuk mengukur ada atau tidaknya pengaruh antara kesadaran merek dan kepercayaan merek sebagai variabel bebas terhadap keputusan pembelian ulang sebagai variabel terikat. Rumus regresi linier berganda sebagai berikut:

$\mathrm{Y}=\mathrm{a}+\mathrm{b}_{1} \mathrm{X}_{1}+\mathrm{b}_{2} \mathrm{X}_{2}+\mathrm{e}$

\begin{tabular}{|c|c|c|}
\hline Variabel & Sig. & Kesimpulan \\
\hline Kesadaran Merek & 0,062 & Tidak terjadi heterokedastisitas \\
\hline Kepercayaan Merek & 0,390 & Tidak terjadi heterokedastisitas \\
\hline
\end{tabular}

Keterangan :

Y : Variabel terikat keputusan pembelian ulang

a : Konstanta

$\mathrm{b}_{1}, . . \mathrm{b}_{2} \quad$ : Koefisien regresi variabel bebas 1 sampai 2

$\mathrm{X}_{1} \quad$ : Variabel bebas kesadaran merek

$\mathrm{X}_{2} \quad$ : Variabel bebas kepercayaan merek

e : error

Analisis Regresi Linier Berganda

Tabel 8. Hasil Analisis Regresi Linier Berganda 


\begin{tabular}{|c|c|c|c|c|c|}
\hline \multirow[b]{2}{*}{ Model } & \multicolumn{2}{|c|}{$\begin{array}{l}\text { Unstandardized } \\
\text { Coefficients }\end{array}$} & $\begin{array}{c}\text { Standardized } \\
\text { Coefficients }\end{array}$ & \multirow[b]{2}{*}{$t$} & \multirow[b]{2}{*}{$\mathrm{Sig}$} \\
\hline & B & $\begin{array}{l}\text { ANOVA } \\
\text { Std.Error } \\
\end{array}$ & Beta & & \\
\hline $\begin{array}{l}1 \text { (Constant) } \\
\text { Model }\end{array}$ & $\begin{array}{c}\text { Sumgof } \\
\text { Squares } \\
\end{array}$ & , 370 & $\begin{array}{c}\text { Mean } \\
\text { Square } \\
\end{array}$ & $F^{2,395}$ & Sig. \\
\hline X1 & -165 & 103, & -,135 & $-1,599$ & 114 \\
\hline $\mathrm{X} 2$ & 882 & 090 & 828, & 9,779 & ,000 \\
\hline
\end{tabular}

a. Dependent Variable: VAR00007

Berdasarkan hasil analisis regresi dapat diketahui persamaan regresi berganda sebagai berikut:

$$
Y=0,887+\left(-0,165 X_{1}\right)+0,882 X_{2}+e
$$

1. Nilai konstanta b sebesar 0,887 dapat diartikan apabila variabel kesadaran merek dan kepercayaan merek dianggap nol, maka keputusan pembelian ulang nilainya sebesar positif 0,887 .

2. Nilai koefisien b pada variabel kesadaran merek sebesar -,165 artinya setiap variabel kesadaran merekmengalamipenurunan sebesar satu satuan, maka keputusan pembelian ulang menurun sebesar ,165 satuan.dengan asumsi variabel bebas yang lain konstan

3. Nilai koefisien b pada variabel kepercayaan merek sebesar ,882 artinya setiap variabel kepercayaanmerekmengalamikenaikan sebesar satu satuan maka keputusan pembelian ulang meningkat sebesar ,882 satuan.dengan asumsi variabel bebas yang lain konstan

\section{Uji t}

\section{Kesadaran Merek}

t hitung $-1,599 \geq-1,99444$ jadi Ho diterima Ha ditolak, maka kesadaran merek secara parsial tidak berpengaruh terhadap keputusan pembelian ulang.

\section{Kepercayaan Merek}

t hitung 9,779>1,99444 jadi Ha diterima Ho ditolak, maka kepercayaan merek secara parsial berpengaruh terhadap keputusan pembelian ulang.

\section{Uji F}

Tabel 9. Hasil Uji F 


\begin{tabular}{|c|c|c|c|c|c|}
\hline 1 Regression & 16,659 & 2 & 8,330 & 53,221 &, $000^{\mathrm{b}}$ \\
\hline Residual & 11,112 & 71 & 157, & & \\
\hline Total & 27,772 & 73 & & & \\
\hline
\end{tabular}

a. Dependent Variable: VAR00007

b. Predictors: (Constant), VAR00006, VAR00005

F hitung 53,221 > F tabel 3,13 jadi Ho ditolak, maka kesadaran merek dan kepercayaan merek secara simultan berpengaruh terhadap keputusan pembelian ulang.

\section{Koefisien Determinasi $\left(R^{2}\right)$}

\section{Tabel 10. Hasil Model Summary}

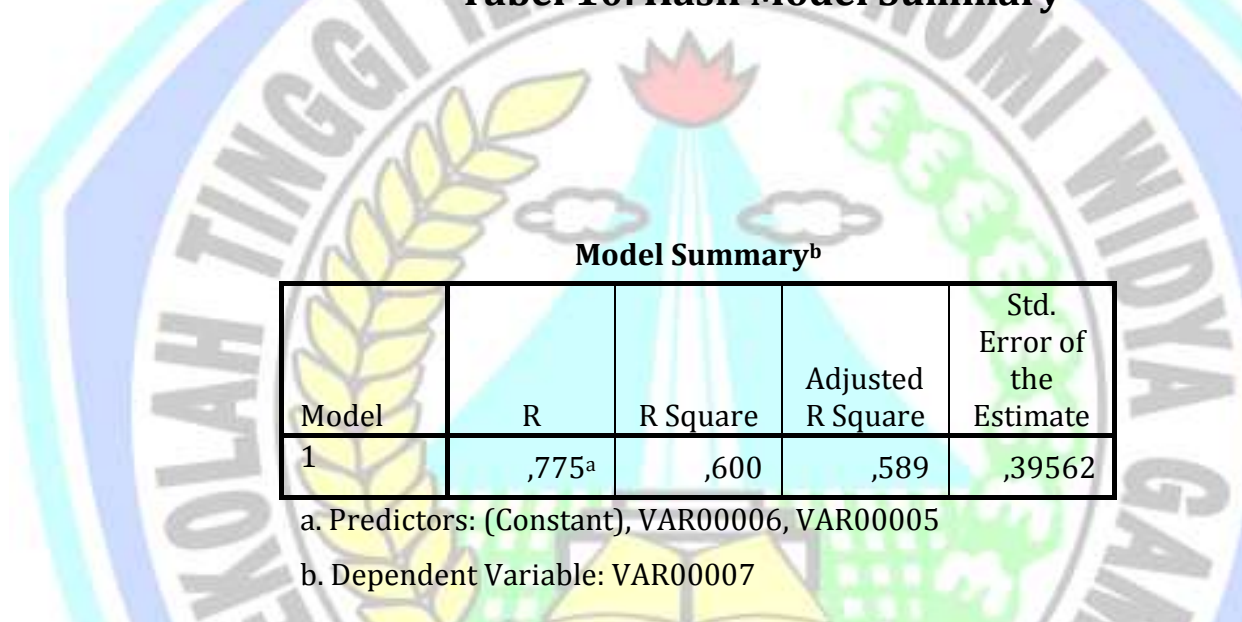

Berdasarkan output tabel Model Summary diperoleh nilai $\boldsymbol{R}^{2}$ (Adjusted $R$ Square) sebesar 0,589. Hal ini menunjukkan bahwa keputusan pembelian ulang di pengaruhi kesadaran merek dan kepercayaan merek sebesar 58,9\%, sedangkan sisanya $41,1 \%$ dipengaruhi faktor lain yang tidak termasuk dalam penelitian ini.

\section{Faktor Dominan}

Pengujian ini dilakukan dengan menggunakan t-test pada regresi linier, yaitu membandingkan nilai $t$ hitung dengan nilai t tabel untuk menuntukan variabel apa yang dominan mempengaruhi variabel $Y$.

1. Kesadaran merek, $\mathrm{t}$ hitung $-1,599<\mathrm{t}$ tabel $-1,99444$ tidak terdapat pengaruh terhadap variabel $Y$

2. Kepercayaan Merek, $\mathrm{t}$ hitung 9,779 $>\mathrm{t}$ tabel 1,99444 terdapat pengaruh terhadap variabel $\mathrm{Y}, \mathrm{t}$ hitung paling besar positif 9,779. Dengan demikian kepercayaan merek merupakan pendorong utama seorang konsumen untuk melakukan pembelian ulang produk smartphone Samsung. 


\section{PEMBAHASAN}

Penelitian ini bertujuan untuk menguji dan mengidentifikasi pengaruh kesadaran merek dan kepercayaan konsumen atas merek terhadap keputusan pembelian ulang produk smartphone samsung.

\section{Pengaruh Kesadaran Merek dan Kepercayaan Merek Terhadap Keputusan Pembelian Secara Parsial}

Hipotesis pertama, "Kesadaran merek dan kepercayaan merek berpengaruh secara parsial terhadap keputusan pembelian ulang produk smartphone samsung." Tidak terbukti kebenarannya.

a. Kesadaran merek secara parsial tidak berpengaruh terhadap keputusan pembelian ulang dengan nilai uji $\mathrm{t}-1,599 \geq-1,99444$. Darmadi (2004:6) Kesadaran merek merupakan salah satu elemen inti dalam brand equity. Kesadaran merek menggambarkan keberadaan merek di dalam pikiran konsumen yang dapat menjadi penentu dalam beberapa kategori dan biasanya mempunyai peranan kunci dalam brand equity. Kesadaran merek tidak berpengaruh secara parsial terjadi karena adanya penurunan indikator dari Top of mind ke Brand Recall di tunjukkan dengan jawaban kuesioner yang mengarah ke ragu-ragu dan sebanyak 60 orang responden mengetahui tentang insiden meledaknya Samsung galaxy note 7 . Hal ini menyebabkan kehawatiran konsumen dalam memakai produk smartphone Samsung dan reputasi Samsung sebagai produsen yang memiliki kualitas yang baik berangsur-angsur ikut pudar.

b. Kepercayaan merek secara parsial berpengaruh terhadap keputusan pembelian ulang dengan nilai uji t 9,779 >1,99444. Kepercayaan merek adalah kekuatan kepercayaan bahwa suatu produk memiliki atribut tertentu. Mowen dan Minor (2002) Kepercayaan merek memiliki peran yang penting untuk membentuk komitmen konsumen terhadap suatu produk, ketika suatu merek tersebut memenuhi kebutuhan dan memberikan kepuasan maka semakin tinggi pula tingkat pembelian produk yang sama di masa yang akan datang, meski Samsung mendapat musibah dengan insiden meledaknya Samsung galaxy note 7 tetapi samsung dengan sigap mencoba menjaga kepercayaan merek yang telah dibangun selama ini dengan berbagai tindakan mulai dari Recall (penarikan samsung galaxy note 7 yang telah beredar), pemberian kompensasi berupa voucer belanja atau potongan pembelian produk smartphone galaxy, pengembalian dana secara penuh dan menggulirkan produk-produk terbaru. Hal ini membuat konsumen merasa aman karena Samsung cepat menanggapi suatu masalah sehingga konsumen tidak dirugikan lebih besar lagi.

\section{Kesadaran Merek dan Kepercayaan Merek Pengaruhnya Secara Simultan Terhadap Keputusan Pembelian}

Hipotesis kedua "Kesadaran merek dan kepercayaan merek berpengaruh secara simultan terhadap keputusan pembelian ulang produk smartphone Samsung." Diterima dan terbukti kebenarannya dengan nilai uji F, F hitung 53,221 > F tabel 3,13 yang artinya secara bersama-sama variabel Kesadaran merek dan kepercayaan merek berpengaruh terhadap keputusan pembelian ulang produk smartphone Samsung. Pembelian ulang menurut Peter dan Olsen (2002) adalah kegiatan pembelian yang dilakukan lebih dari satu kali atau beberapa kali. Kepuasan yang diperoleh konsumen dapat mendorong ia melakukan pembelian ulang menjadi loyal 
terhadap produk tersebut sehingga konsumen dapat menceritakan hal-hal yang baik kepada orang lain.

Semakin tinggi kesadaran merek semakin baik calon pembeli untuk mengenali dan mengingat merek hal ini membuat seseornag untuk membeli merek tersebut semakin tinggi tentu saja jika di imbangi dengan kepercayaan merek maka akan semakin besar seseorang untuk melakukan pembelian ulang kembali di masa yang akan datang.

\section{Kepercayaan Merek Berpengaruh Dominan Terhadap Keputusan Pembelian}

Hipotesis ketiga "Kepercayaan merek berpengaruh dominan terhadap keputusan pembelian ulang produk smartphone Samsung." Diterima dan terbukti kebenarannya. Kepercayaan merek menjadi variabel dominan karena memiliki nilai uji t yang lebih besar dari pada kesadaran merek dan secara parsial berpengaruh terhadap keputusan pembelian ulang produk smartphone Samsung. Hal ini menunjukkan bahwa tingkat kepercayaan merek pengguna smartphone Samsung terjaga dengan baik meskipun kesadaran merek mengalami penurunan akibat insiden meledaknya Samsung galaxy note 7. Sikap tanggap dan pemilihan keputusan yang tepat dengan melakukan Recallproduk smartphone galaxy note 7 dan pemberian kompensasi membuat Samsung berhasil mempertahankan kepercayaan merek terhadap produk-produk smartphonenya.

\section{PENUTUP}

Simpulan

Berdasarkan hasil analisis dan pembahasan, tentang pengaruh kesadaran merek dan kepercayaan merek terhadap keputusan pembelian ulang produk smartphone Samsung dapat ditarik kesimpulan sebagai berikut:

1. Kesadaran merek secara parsial tidak berpengaruh terhadap keputusan pembelian ulang.

2. Kepercayaan merek secara parsial berpengaruh terhadap keputusan pembelian ulang.

3. Kesadaran merek dan kepercayaan merek secara simultan berpengaruh dan signifikan terhadap keputusan pembelian ulang.

4. Kepercyaan merek adalah variabel yang dominan dalam mempengaruhi keputusan pembelian ulang.

\section{Saran}

Berdasarkan hasil penelitian, pembahasan dan kesimpulan yang diperoleh maka saran yang dapat di berikan sebagai berikut :

1. Bagi Perusahaan

a. Berdasarkan hasil penelitian diketahui bahwa ada penurunan pada penilaian responden terhadap indikator Top of Mind dan Brand Recall konsumen banyak memilih ragu-ragu terhadap produk smartphone Samsung pasca meledaknya samsung galaxy note 7. Perusahaan disarankan meningkatkan kesadaran merek, dengan cara memberikan informasi kepada masyarakat mengenai keberadaan merek melalui berbagai media misalnya media cetak, elektronik dan sosial.

b. Samsung sebaiknya lebih memperhatikan variabel kepercayaan merek yang diterapkan dalam perilaku konsumen, karena dari hasil penelitian ini terbukti bahwa variabel kepercayaan merek berpengaruh dominan terhadap keputusan pembelian ulang. Samsung dapat meningkatkan 
kepercayaan merek dengan cara memenangkan penghargaan atau awards misalnya top brand award, selular award dan product design award

2. Peneliti Selanjutnya

Bagi peneliti selanjutnya disarankan untuk melakukan peelitian di luar variabel bebas dari penelitian ini. Peneliti selanjutnya juga dapat menggunakan metode lain dalam meneliti keputusan pembelian ulang misalnya wawancara mendalam terhadap responden, sehingga informasi yang di peroleh dapat lebih bervariasi dari pada angket jawaban yang telah tersedia.

\section{DAFTAR RUJUKAN}

Aaker, David A. 2008. Manajemen Ekuitas Merek: Memanfaatkan Nilai dari suatu Merek. Terjemahan oleh Aris Ananda. Cetak ketiga. Jakarta

Durianto, Darmadi, Sugiarto dan Lie Joko Budiman, 2004. BRAND EQUITY TEN Strategi Memimpin Pasar. Jakarta: PT Gramedia Pustaka Utama.

Delgado-Ballester, Elena, Munuera-Aleman, Jose Louis \& Yague-Guillen, Maria Jesus. 2003. Development and Validation of A Brand Trust Scale International. Journal Of Market Research, Vol45/1, p, 35-53

Darmawan, dkk. 2016. Perbandingan Ekuitas Merek Indomie Dan Mie Sedap. Jurnal Manajemen, (online), vol. 8, No.2, (\{ HYPERLINK "http://journal.feb.unmul.ac.id" \}, diakses 3 April 2017)

Ghozali, Imam. 2016. Aplikasi Multivariete dengan Program SPSS IBM23. Semarang: Badan Penerbit Universitas Diponegoro Semarang

Hendar, Siyamtinah.2015. Meningkatkan Pembelian Ulang Melalui Kepercayaan dan Kepuasan pada Pembelanjaan ONLINE. UNISSULA ISSN 2302-9791. Vol. 2 No.1 May 2015 (diakses 3 april 2017)

Hartono \&Yunita N.2013.Analisa Pengaruh Retail Mix (Costumer Service, Location, Store Design \& Display, Merchandise Assortmen, Communication Mix dan Price)Terhadap tingkat kunjungan di toko Souvenir Ken N So Surabaya). Jurnal Manajemen Petra Vol 1, No. 2

John C Mowen, Michael Minor, 2002, Perilaku Konsumen, Jakarta : Erlangga

Kotler, Philip \& Kevin Lane Keller. 2009. Manajemen Pemasaran, Edisi Ketiga Belas, jilid 1.Jakarta: Erlangga

Muzaqqi, dkk. 2016. Pengaruh Kesadaran Merek, kesan Kualitas, Asosiasi Merek, dan Loyalitas Merek Terhadap Ekuitas Merek (Survei Pada Konsumen Pembeli Dan Pengguna Produk Sari Apel Siiplah Di perumahan Saxophone Kecamatan lowokwaru Kota Malang). Jurnal 
Admistrasi Bisnis, (online), Vol. 31, No.1, (\{ HYPERLINK "http://administrasibisnis.stoudentjournal.ub.ac.id" $\boldsymbol{Z}$ diakses 4 April 2017)

Nazir, Moh., 2014. Metode penelitian. Bogor: Ghalia Indonesia

Peter, J. Paul dan Olson, Jerry C. 2002. Consumer Behavior : Perilaku Konsumen dan Strategi Pemasaran. Edisi keempat. Jilid 1. Jakarta : Erlangga

Priyatno Duwi. 2016. Belajar Alat Analisis Data dan Cara Pengolahannya dengan SPSS. Yogyakarta: Gava Media

Sugiyono. 2016. Metode Penelitian Kuantitatif, kualitatif, dan R\&D. Bandung: Alfabeta

Supranto, J \& Nandan Limakrisna. 2011. Perilaku Konsumen Dan Strategi Pemasaran Untuk Memenangkan Persaingan Bisnis. Jakarta: Mitra Wacana Media.

Sumarwan, Ujang. 2015. Perilaku Konsumen Teori Dan Penerapannya Dalam Pemasaran. Bogor: Ghalia Indonesia

Suwitho, Sibut. 2016. Pengaruh Bauran Pemasaran Terhadap Keputusan Pembelian Ulang Konsumen Minimarket ALfAMART Di Surabaya.Jurnal Ilmu dan Riset Manajemen, (online), Vol. 5, No 1, Januari 2016, (\{ HYPERLINK "https://ejournal.stiesia.ac.id" \}, diakses 3 april 2017)

Sangadji, Etta Mamang \& Sopiah. 2013. Perilaku Konsumen "Pendekatan Praktis Disertai Himpunan Jurnal Penelitian. Yogyakarta: CV ANDI OFFSET

Swasty, Wirania. 2016. Branding "Memahami Dan Merancang Strategi Merek". Bandung: PT. REMAJA ROSDAKARYA

Sujaratna W.2016. SPSS untuk Penelitian.Yogyakarta: Pustaka Baru Press

Sujarweni V Wiratna. 2015. SPSS Untuk Penelitian. Yogyakarta; Pustaka Baru Press

Tjiptono, Fandy. 2011. Manajemen \& Strategi Merek.Yogyakarta: CV ANDI OFFSET

Tjiptono, fandy. 2008. Strategi Pemasaran. Yogyakarta: Andi

Umi, Narimawati., Sri Dewi, Anggadini., Linna, Ismawati. (2011), Penulisan Karya Ilmiah, Edisi Pertama, Genesis. Pondok Gede, Bekasi 
Wulansari, Anette (2013). Pengaruh Brand Trust dan Perceived Quality terhadap keputusan Pembelian Ulang.Jurnal Ilmu Manajemen, (Vol 1 nomer 2 Maret, diakses 3 April 2017)

Wirawan, Sonang. 2016. Pengaruh Produk, Harga, Promosi, dan Merk Terhadap Keputusan Pembelian Ulang.Jurnal Ilmu dan Riset Manajemen Vol 4, No. 10, Oktober 2015 diakses 3 April 2017)

.2017. IDC Smartphone Market Share Vendor (\{ HYPERLINK "http://www.idc.com" \}, diakses 3 april 2017).

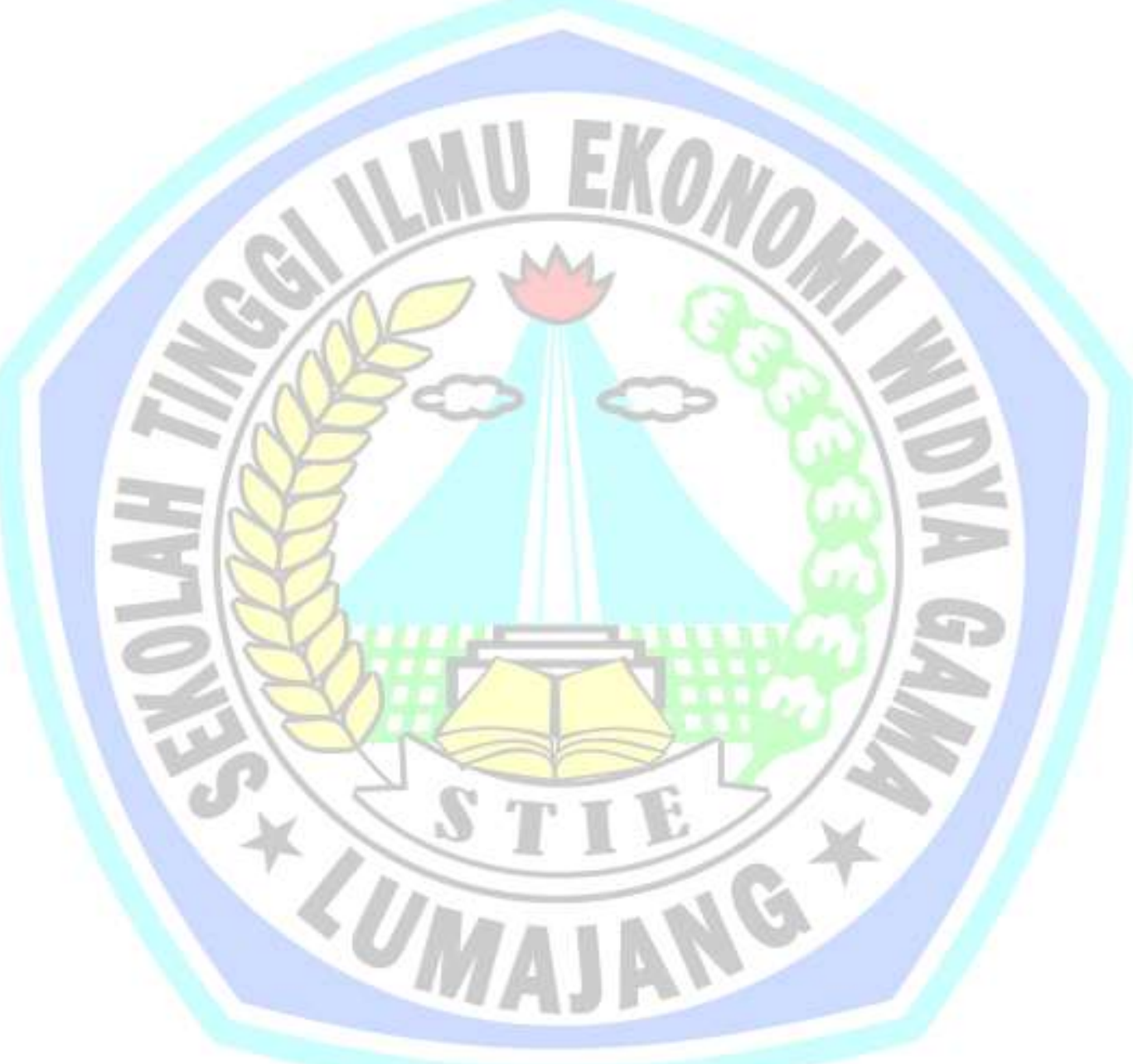

